\title{
Management Capabilities and Corporate Environmental Performance: The Moderating Role of Top Management Team Faultlines
}

\author{
Wuwei Li ${ }^{1,2, ~ *, ~ Y u a n y u a n ~ Z h a n g ~}{ }^{1}$, Yueru Wei ${ }^{3}$ \\ ${ }^{1}$ School of Business Administration, Zhengzhou University of Aeronautics, Zhengzhou, China \\ ${ }^{2}$ Collaborative Innovation Center for Aviation Economy Development of Henan Province, Zhengzhou, China \\ ${ }^{3}$ School of Business Administration, Zhengzhou University of Technology, Zhengzhou, China
}

Email address:

liwuwei1981@163.com(Wuwei Li)

${ }^{*}$ Corresponding author

\section{To cite this article:}

Wuwei Li, Yuanyuan Zhang, Yueru Wei. Management Capabilities and Corporate Environmental Performance: The Moderating Role of Top Management Team Faultlines. Science Journal of Business and Management. Vol. 6, No. 1, 2018, pp. 22-31.

doi: 10.11648/j.sjbm.20180601.14

Received: April 19, 2018; Accepted: June 21, 2018; Published: June 26, 2018

\begin{abstract}
This study empirically analyzes the impact of management capabilities on corporate environmental performance and the moderating role of top management team faultlines including task-related faultlines and bio-demographic faultlines in the Chinese context. This study uses a sample of 163 Chinese chemical firms and hierarchical regression analysis to test the proposed hypotheses. The results show that management capabilities have a significant and positive influence on environmental performance of the firms. In addition, top management team task-related faultlines have a significant and positive moderating effect on the relationship between management capabilities and environmental performance of the firms, whereas top management team bio-demographic faultlines have a significant and negative moderating effect on the relationship between management capabilities and environmental performance of the firms. According to the results, this study puts forward some theoretical and practical implications. This study contributes to the literatures on the top management team faultlines and environmental management, especially to the literatures on the mechanism for how management capabilities influence corporate environmental performance.
\end{abstract}

Keywords: Management Capabilities, Environmental Performance, Top Management Team Faultlines

\section{Introduction}

A firm's management capabilities are the key to increase the competitive advantage under the dynamic environment. The management capabilities are the systematic and complex capabilities that combine greater conceptual, human and technical capabilities [1]. These capabilities can provide the firms with the efficient support to recognize and make use of external opportunities, avoid the threats from external environment, and integrate the resources from internal and external environment effectively. Management capabilities play an essential role during the process of making organizational strategy and routine. From an empirical perspective, several scholars analyzed the influence of management capabilities on firm performance, and it has been proved that the stronger the management capabilities the firms receive, the better the firms' innovation and growth performance will become $[2,3]$.

Environmental performance has close relation with the sustainable development of the firms, because environmental performance has been become an important pathway for the firms to obtain the excellent competitive advantage [4]. Particularly in China, with the rapid growth of economy over the past more than 30 years, pollution has become more serious and has attracted the attentions of the scholars and government. Existing relevant literatures have mainly 
explored pollution issues in terms of environmental and innovation economics [5]. Exploring the micro-level origins of boosting environmental performance has been an important task for the top managers in the firms, but seldom studies on discussing the factors influencing environmental performance from the perspective of top management team are found. In fact, top management team is responsible for the strategic decisions which guide the firms' sustainable development [6]. Therefore, the level of environmental performance of the firms is closely related with the management capabilities from the top managers in the firms. Existing researches show that top management team diversity can influence the firm performance and its innovation activities [7]. Compared to the traditional theory on team diversity, team faultlines theory proposed by Lau and Murnighan has been regarded as an important emerging theory to explore the effect of team diversity on team outcomes $[8,9]$.

As have discussed above, many studies support the viewpoint that the team faultlines are more precise for measuring the level of team diversity, including the diversity of top management team. While the importance of team faultlines is generally recognized from the theoretical perspective, the empirical results of its influence on team performance are mixed. In fact, while several empirical studies show that faultlines have a negative impact on team outcomes, other empirical studies stress that faultlines have a significant and positive impact on team performance. Several possible reasons for the above mixed results are that the investigated teams or firms are located in the different countries or regions, and the measurements for team faultlines are inconsistent. Many scholars investigated a single faultline hinging on multiple characteristics of the members [10]. However, it has been argued that it is difficult to identify which one or which ones may result in the observed effect when employing the more kinds of the characteristics of the members [11]. In order to solve the problems related with how to identify the effects of team faultlines, scholars divide the team faultlines into two categories, including task-related faultlines and bio-demographic faultlines [12]. Accordingly, this study investigates the moderating role of two kinds of faultlines, namely task-related faultlines and bio-demographic faultlines on the relationship between management capabilities and environmental performance of the firms.

Based on previous discussion, this study aims to provide some new contributions on the relationship between management capabilities and corporate environmental performance achieved by considering the top management team faultlines. Specifically, this study empirically analyzes the influence of management capabilities on corporate environmental performance through employing the data on 163 Chinese chemical firms, and the role of top management team faultlines as a moderating variable for this relationship.

The remainder of the paper is structured as follows. The next section presents literature review and hypotheses development. Section 3 puts forward the methodology including sample and variable measurement. Section 4 and Section 5 discuss the results, theoretical and practical implications, respectively. Finally, the conclusion is given.

\section{Literature Review and Hypotheses Development}

\subsection{The Influence of Management Capabilities on Corporate Environmental Performance}

The top management team is responsible for analyzing information on external environment in which the firms operate, making the firms' strategic decisions, and selecting the proper development paths to achieve the strategic objectives of the firms. The top management team with strong management capabilities plays a key role for the sustainable development of the firms, particularly for SMEs [2]. It has been shown that lacking of management capabilities is harmful for the firms to achieve growth [13], and management capabilities enable the firms to achieve the stable development.

Management capabilities involve with the capabilities, with which the top managers can analyze the information from external environment, select the proper strategic directions, recognize the chance, and integrate internal and external resources [2]. These capabilities have a significant and positive effect on analyzing external environment, establishing their core competence, and achieving the strategic goal. This study proposes the influence of management capabilities on corporate environmental performance.

In order to achieve the firms' development, it is essential for the firms to establish the top management team with strong capabilities to make the proper general strategy and integrate internal and external resources. During the process of achieving the firms' sustainable development, boosting environmental performance plays a crucial role. Dubey et al. stressed that greater environmental performance needed top managers to integrate and distribute several resources [6]. In this respect, strong management capabilities are vital for the firms to achieve the greater environmental performance and sustainable development.

As have been discussed previously, greater environmental performance is important for the firms to achieve their sustainable development. Some studies suggested that greater environmental performance required the firms to optimize the participation of top management team [6]. According to the study by Katz [1], management capabilities combine conceptual, human and technical capabilities. As for the top managers, the most important of which are conceptual capabilities. Conceptual capabilities involved with the capabilities which enable the top managers to recognize the opportunities and threats from the external complex environment [14]. Management capabilities, including conceptual capabilities are essential for the firms to accumulate the competitive advantage, achieve the sustainable development and boost environmental innovation [15]. Hence, this study proposes the following hypotheses:

H1. Management capabilities positively influence 
environmental performance of the firms.

\subsection{The Moderating Effect of Top Management Team Faultines on the Relationship Between Management Capabilities and Corporate Environmental Performance}

As have been discussed above, in order to achieve greater environmental performance, the top managers in the firms need abundant knowledge and resources to seek for opportunities, identify the potential threats, and set up strategic target. The knowledge is very important for the top management team to achieve the information processing related to the environmental performance of the firms. That is, boosting environmental performance for the firms largely depends on the top managers' capabilities on gathering, sharing, analyzing relevant information, and integrating them to make proper decision effectively. Top management team with diverse experience and knowledge is inclined to get abundant information and be better position to make proper solutions, when facing with the complex problems. In addition, in the process of sharing and analyzing information, it has been documented that the stereotypic and affective perception of the members in top management team have negative influence [16]. One important purpose of this study is to investigate the moderating role of top management team faultlines on the relationship between management capabilities and corporate environmental performance. Following the previous research [12], this study divides top management team faultlines into two types including task-related faultlines and bio-demographic faultlines, because the distinctions for the effect of the two categories of team faultines has been confirmed by the relevant studies that employ the meta-analysis.

\subsubsection{The Moderating Effect of Top Management Team Task-Related Faultines on the Relationship Between Management Capabilities and Corporate Environmental Performance}

Task-related faultlines involve with the accumulated knowledge and capabilities associated with the particular tasks which the members refer to [8]. These task-related faultlines associated with boosting management capabilities mainly involve with organizational tenure, functional background and educational level. As this study has discussed above, information processing is very important for the top managers to obtain stronger management capabilities. It has been proved that functional background, educational level and tenure have significant influences on information processing of top managers [17], and further affect the management capabilities. While it has been suggested that top managers with longer tenure may obtain more explicit and tacit knowledge of the firms, and may achieve the resource integration, the negative effect of longer tenure on increasing the information processing of top management team is obvious. Top managers with longer tenure are not inclined to garner the new information and skill for employing external opportunities [18], they may protect their managerial reputation position. In contrast, the top managers with shorter tenure are inclined to obtain the new knowledge, and gather the opportunities from the external environment, and broaden the top management team identification [19].

The second task-related characteristic in this study is educational level [8]. The educational experiences of the top managers in a firm play an important role in accumulating not only the knowledge and skill, but also capabilities of their strategic formulation. Top managers with higher educational level are inclined to accumulate the stronger management capabilities [17], and to make the strategies in a long term, which is beneficial for the firms to achieve the sustainable development and boost environmental performance.

The third task-related characteristic discussed in this study is functional background [8]. When discussing the complex problems, the top managers with different functional background may adopt the different perspectives. Consequently, facing with the complex problems, it is easier for top managers with different functional background to exchange their different viewpoints. The constructive exchange is beneficial to form the better solution. It has been shown that top management team with diverse functional background enables the firms to increase their performance.

When the task-related characteristics of a few members in a team are same or similar, and these characteristics are different from those of other members, the subgroups with different task-related characteristics are more likely to be formed within a team. The members in a task-related subgroup often have similar knowledge, perspectives and mental models because of their similar task-related background [12]. This is beneficial for the firms to obtain the diverse information on decision-making due to different task-related background. Stronger task-related faultlines may be better to achieve the information processing effectively. It has been suggested that the members are more likely to share their ideas and information when they find that at least one other member hold the view of point which is same or similar with theirs [20]. Consequently, the members in the team are inclined to express their options freely when discussing the problems if they believe that there is alignment in their subgroup [21]. It has been shown that it is impossible for the members of a team to pay equal attention to discuss the problems and give options, because of information overload by attending to lots of different viewpoints [22]. It has been argued that the value of a team is that it can enables the members to analyze the problems and put forward the solutions as a whole, if the members are likely to give their options [23]. Therefore, task-related information is vital for a subgroup in top management team to solve the problems [10].

In addition, several studies have shown that the teams with stronger faultlines are beneficial for employing the diverse task-related knowledge of the members in different task-related subgroups [24]. While sometimes a few task-related conflicts may be emergent due to the different task-related knowledge and perspectives of the members in different task-related subgroups, these conflicts are often constructive and have a positive effect on information 
processing. It has been confirmed that the members from different task-related background are likely to gather more diverse information processing capabilities and more diverse strategies [12]. While researches show that task-related faultlines may not be important for the teams when coping with the simple and routine work [16], it has been found that under the complex environment, task-related faultlines enable the team to achieve information processing effectively [25]. When facing with the complex and non-routine work, especially under the uncertainty, the top management teams urgently require diverse task-related background to achieve information processing effectively. To summarize, it is complex and non-routine for the firms to boost environmental performance, which requires the top management teams to better achieve the information processing. This study argues that top management team with stronger task-related faultlines may be better position to exert information processing, which is beneficial to foster environmental performance. Hence, this study proposes the following hypotheses:

H2. Top management team task-related faultlines positively moderate the relationship between management capabilities and corporate environmental performance.

\subsubsection{The Moderating Effect of Top Management Team Bio-Demographic Faultines on the Relationship Between Management Capabilities and Corporate Environmental Performance}

As have been discussed above, faultlines strength can influence on information processing, and influence the team decisions and team performance. While a series of researches have shown that task-related faultlines have a positive effect on team outcomes, some researches find that the formed subgroups depended on the bio-demographic characteristics are negative to team outcomes [26]. Bio-demographic characteristics involve with gender, age, nationality or ethnicity [8]. These characteristics are innate and can be correctly cognitively accessible, and hardly alternative [27]. Due to high visibility of these bio-demographic characteristics, they are easily considered for the members to form the perception of other members in a team according to the latter's bio-demographic characteristics [28]. More specifically, bio-demographic characteristics are considered to be associated with the stereotypic beliefs. When the bio-demographic faultlines are activated, team members will make perception of other members in a team according to the different bio-demographic characteristics. Under the circumstances of stronger bio-demographic faultlines, activation for bio-demographic faultlines is likely to form the biased perceptions of other members. Lau and Murnighan proposed that the more aligned for multiple bio-demographic characteristics of several members in a team, the more salience of differences between them and other members [8]. Consequently, stronger bio-demographic faultlines reinforce the differences between the members and the biased perceptions of other members, which is harmful for the team to achieve information processing effectively.

In addition, researches have shown that the members of a team are inclined to view their stereotypes related to their own bio-demographic characteristics in overly positive terms to set up a positive self-image. In contrast, the stereotypes which are not associated with the bio-demographic characteristics of the members are regarded as negative elements by them. Meanwhile, researches have suggested that the negative impact of the bio-demographic characteristics may be weaken if some of the characteristics of the members in a team are cross-cutting [29]. In a team with stronger faultlines, the characteristics of the members in a subgroup are in align, and the formed subgroups are distinct and salient, that is, the bio-demographic characteristics between the different subgroups are obviously different, which may lead to emotional conflict. Under this circumstance, the mistrust and hostility toward the members of other subgroups may be emergent and may be strengthen, when the differences derived from the bio-demographic characteristics arrive at a certain level $[30,31]$. When the situation arrives, the members in the different subgroups are inclined to consider the difference taken root in the bio-demographic characteristics, and not the knowledge and task-related skills of the members in other subgroups [16]. In that case, it is difficult to achieve the complex information processing [32]. The members in the different subgroups are not inclined to share and exchange information positively [33]. Simons and Peterson stressed that the anxiety generated from emotional conflict were harmful for the members in different subgroups in a team to carry out information processing and exchange [32].

To sum up, in a top management team with stronger bio-demographic faultlines, the top managers in different subgroups may trigger stereotypes that lead to the bias and emotional conflict of the members in one subgroup toward to the members in other subgroups. These are not beneficial for top management team to carry out information exchange and processing. Consequently, it is difficult for top management team with stronger bio-demographic characteristics to cope with the complex issues that require sufficiently information exchange and processing. Exploring the path to improve corporate environmental performance is a typical systematical issue and it requires top managers to achieve information processing and make appropriate the strategies for the firms. Hence, this study proposes the following hypotheses:

H3. Top management team bio-demographic faultilines negatively moderate the relationship between management capabilities and corporate environmental performance.

\section{Methodology}

\subsection{Sample}

The members of the research group got in touch with the top managers including CEO or senior executives of Chinese chemical firms. 226 chemical firms agreed to provide the relevant data on demographic characteristics of top management team and other information, such as environmental performance, firm age, firm size, etc. This study asked the top managers to persuade all top management 
team members to participate, if possible. Top managers as participants independently achieve their surveys related to their individual characteristics and enclosed questionnaires finished by them in the certain envelopes provided by the research group.

The members of the research group first received 226 questionnaires. This study excluded 51 questionnaires in which individual responses with incomplete demographic characteristics of top managers, that are required to measure the faultlines of top management team are shown [8]. Further, this study eliminated 12 questionnaires with top management teams whose composition numbers are fewer than four because subgroups within these top management teams were confirmed to exhibit different dynamics [23]. Finally, the effective sample was 163 firms and their top management teams with 1029 members. Concerning the firm age, the firms whose age were below 6 accounted for 7.36 percent, and those whose age ranged from 6 to 10 accounted for 9.82 percent, and those whose age ranged from 11 to 15 accounted for 20.25 percent, and those whose age ranged from 16 to 20 accounted for 30.06 percent, and those whose age ranged from 21 to 25 accounted for 19.63 percent, and those whose age ranged above 25 accounted for 12.88 percent. Concerning the firm size, the firms whose employee number were below 100 accounted for 15.95 percent, and those whose employee number ranged from 100 to 150 accounted for 27.61 percent, and those whose employee number ranged from 151 to 200 accounted for 22.70 percent, and those whose employee number ranged from 201 to 250 accounted for 26.38 percent, and those whose employee number were above 250 accounted for 7.36 percent. In addition, the firms whose location were in the eastern region of China accounted for 42.94 percent, and those whose location are in the central and western region of China accounted for 57.06 percent.

\subsection{Variables Measurement}

The variable measurements used in this paper are all constructed from prior studies. This study designed the questionnaires in Chinese using the conventional backtranslation process to ensure translation equivalence. For all measurement items except the characteristics for top management team and control variables including firm size, firm age, regional location, this study used seven-point Likert scales to measure them.

\subsubsection{Dependent Variable}

As Long et al. have stated [5], organization performance can be investigated by two aspects including subjective and objective measurements. Due to the restriction for obtaining the objective data, this study adopts subjective measurements. The measurement scale for corporate environmental performance used in this study was development by Long et al. [5]. This study uses four-item measurement scales to measure corporate environmental performance $(\alpha=0.92)$.

\subsubsection{Independent Variable}

This study uses nine-item measurement scales to measure management capabilities $(\alpha=0.93)$. Concerning the detailed information on measurement for management capabilities, please refer to study by Ruiz-Jiménez [2].

\subsubsection{Moderator Variables}

As have discussed above, this study investigates the moderating effect of top management team faultlines from two aspects, which consist of task-related faultlines and bio-demographic faultlines. When measuring task-related faultlines of top management team, this study considers three characteristics including functional background, educational level, and tenure. According to Hambrick and Mason [34], the functional background mainly involves with throughput functional background and output functional background. They suggest that throughput functional background incorporates production, finance or accounting, human resource management, administration, and legal functional background, and output functional background incorporates marketing and R\&D functional background. Therefore, this study divides the functional background into two categories including throughput functional background and output functional background (coded 1 if the top manager had functional background and 0 otherwise). Educational level was divided into four intervals, below junior college was coded 1 , undergraduate was coded 2 , postgraduate was coded 3 , doctor was coded 4 . Tenure was measured through the number of years of being the members in top management team. When measuring bio-demographic faultlines, this study uses sex and age which were usually used in relevant literatures [12].

This study measures top management team task-related and bio-demographic faultlines by calculating the overall score through multiplying the faultlines strength and faultlines distance. The calculation principle and detailed calculation steps adopted in this study has been widely used in prior studies [25].

\subsubsection{Control Variables}

In order to address the endogenous problems and more precisely investigate the relationship between the above variables, this study controls for the following additional variables.

Financial performance. Given the differences in the firm size, firm age and regional environment, this study adopts subjective evaluation method to measure the firms' financial performance through establishing the two-items related to return on assets, return on equity, based on the prior study [35].

Firm size. This close relationship between firm size and corporate environmental performance has also been proved [36]. Therefore, this study chooses firm size as an important control variable. This study measures firm size by measuring the employee number which was divided into five intervals. Specifically, the firms whose employee number were below 100 were coded 1 , and those whose employee number ranged from 100 to 150 were coded 2, and those whose employee number ranged from 151 to 200 were coded 3 , and those whose employee number ranged from 201 to 250 were coded 4, and those whose employee number is above 250 were coded 5 . 
Firm age. Boosting firm performance including environmental performance is a crucial part of the firms' competitive behavior which was influenced by the firms' resource and growth accumulation [37]. Firm age has been regarded as an important reflection of the growth accumulation. Consequently, this study regards firm age as an important control variable and divides it into six intervals. The firms whose age were below 6 were coded 1, and those whose age ranged from 6 to 10 were coded 2 , and those whose age ranged from 11-15 were coded 3, and those whose age ranged from 16-20 were coded 4, and those whose age ranged from 21 to 25 were coded 5, and those whose age are above 25 were coded 6 .

Regional location. Prior studies have suggested that the environmental pressures from the stakeholders are different due to the difference in the developed and developing areas [38], and it has been confirmed that the top managers were paid more attentions in the developed areas [39]. In China, the level of regional development of the eastern region is higher than that of the central and western region. Therefore, this study divided the region in which the firms operate into two categories, that is, the eastern region of China was coded 1 , and the central and western region of China was coded 0 .

\subsection{Validation of Measures}

In order to ensure the validity of the data obtained, the questionnaires assured all respondents of confidentiality. The researchers involved with this research explained the relevance of this study and offered a standard report of the findings as a reward for participants.

First, this study performed the test for potential biases in the respondents' answering behavior through analyzing the sample for non-response bias by achieving a comparison of early and late respondents. This study performed the Kolomogorov-Smirnov test and Mann-Whitney test, the results show that there are not significant differences for early and late respondents. Therefore, it is reasonable for us to believe that there is no non-response bias in this study.

Second, this study performed Harman's single-factor test to conform whether there is a common method bias or not in the investigated data. This study performed factor analysis for the item data of dependent variable, independent variable, and control variable only involved with financial performance. The results show that three primary factors are extracted, and the contribution rate is 28.56 percent which is lower than 40 percent, indicating that there is not a common method bias in the sample data.

Third, for all multi-item scales including environmental performance, management capabilities, financial performance, this study constructs and integrates confirmation factor analysis to pursue the test for convergent and discriminant validity. Each item is constrained to load only to its respective latent variable. The confirmation factor analysis results show that a good fit within the model $\left(\chi^{2} / d f=2.826, \mathrm{GFI}=0.946, \mathrm{AGFI}=0.931\right.$, $\mathrm{CFI}=0.951$, RMSEA $=0.039, \mathrm{RMR}=0.052$ ), indicating that the convergent and discriminant valid of the scales is credible.

\section{Results}

Table 1 presents the summary statistics and Pearson correlation between the different variables, including dependent variable, independent variable, and control variables.

This study employs moderated multiple regression analysis to finish the test for the hypotheses proposed. This study applies standardized variables in order to avoid the multi-collinearity. Therefore, the interaction terms with top management team faultlines and management capabilities were also established with these standardized variables [40]. In addition, only one interaction term was added in each model. This study calculates the values for variance inflation factors (VIF) for all models in order to check for potential multi-collinearity. The results show that all values for VIF of all factors are below 5, so it is reasonable that the regression results were not influenced by multi-collinearity. The regression analysis results are shown in Table 2.

The first block in Table 2 only contains the control variables and top management team task-related faultines and bio-demographic faultlines (Table 2, model 1). The regression results for the first model indicate that the control variables including financial performance, firm size, firm age, and regional location all have significant influence on environmental performance of the firms. Further, the predictor in the first model for top management team task-related faultlines have a significant and positive influence on corporate environmental performance, whereas top management team bio-demographic faultlines have a significant and negative influence on corporate environmental performance (Table 2, model 1).

The second block in Table 2 contains the independent variable in order to test H1 (Table 2, model 2). The two-way interaction term with top management team task-related faultlines and management capabilities, and the two-way interaction term with top management team bio-demographic faultlines and management capabilities are contained in the third block and in the fourth block to test $\mathrm{H} 2$ and $\mathrm{H} 3$ (Table 2, model 3 and model 4).

The influence of management capabilities on corporate environmental performance (Table 2, model 2) is significant and positive, confirming H1. In order to ensure that the interactions with top management team faultlines and management capabilities were illustrated clearly, this study plotted the significant interactions (Figure 1) through dividing the independent variables into higher and lower categories, one standard deviation above and below the mean, respectively.

The interaction term with top management team task-related faultlines and management capabilities is significant and positive for corporate environmental performance (Table 2, model 3: $\beta=0.168, \mathrm{p}<0.01)$. The value for the explained variance for this model (Table 2, model 3, 19.6 percent) added 3.8 percent to the explained variance shown in model 2 (Table 2 , 15.8 percent). The illustration of this influence (Figure 1a) indicates that as for the firms with stronger top management team task-related faultlines, those with higher level of 
management capabilities will bring more environmental performance than those with the weaker level of management capabilities. In other words, as for the firms with strong top management team task-related faultlines, their environmental performance increases when the level of management capabilities increases. That is, top management team task-related faultlines have significant and positive moderating effect on the relationship between management capabilities and corporate environmental performance, so $\mathrm{H} 2$ is confirmed.

The interaction term with top management team bio-demographic faultlines and management capabilities is significant and negative for corporate environmental performance (Table 2, model 4: $\beta=-0.097, \mathrm{p}<0.01$ ). The value for the explained variance for this model (Table 2, model 4, 19.8 percent) added 4.0 percent to the explained variance shown in model 2 (Table 2, 15.8 percent). The illustration of this influence (Figure 1b) indicates that as for the firms with strong top management team bio-demographic faultlines, their environmental performance decreases when the level of management capabilities increases. That is, top management team bio-demographic faultlines have significant and negative moderating effect on the relationship between management capabilities and corporate environmental performance, so $\mathrm{H} 3$ is confirmed.

Table 1. Summary statistics and Pearson correlation.

\begin{tabular}{lllllllllll}
\hline & Mean & SD & $\mathbf{1}$ & $\mathbf{2}$ & $\mathbf{3}$ & $\mathbf{4}$ & $\mathbf{5}$ & $\mathbf{6}$ & $\mathbf{7}$ \\
\hline $1 . E P$ & 4.567 & 1.052 & 1 & & & & & & \\
$2 . F P$ & 4.692 & 0.971 & 0.325 & 1 & & & & & \\
3. $F S$ & 2.816 & 1.203 & 0.202 & -0.127 & 1 & & & & \\
$4 . F A$ & 3.834 & 1.398 & 0.105 & 0.095 & 0.142 & 1 & & & \\
$5 . R D$ & 0.429 & 0.497 & 0.073 & 0.163 & 0.051 & 0.038 & 1 & & \\
$6 . M C$ & 5.363 & 1.045 & 0.537 & 0.296 & 0.146 & 0.203 & 0.112 & 1 & \\
$7 . T R F$ & 0.126 & 0.163 & 0.208 & 0.154 & 0.117 & 0.096 & 0.082 & 0.104 & 1 \\
$8 . B D F$ & 0.232 & 0.147 & -0.185 & -0.216 & -0.175 & -0.073 & 0.067 & -0.159 & -0.072 & 1 \\
\hline
\end{tabular}

Notes: Variable definitions: EP, environmental performance; FP, financial performance; FS, firm size; FA, firm age; RD, regional development; MC, management capabilities; TRF, top management team task-related faultlines; BDF, top management team bio-demographic faultlines. The same variable definitions are as follows in Table 2.

Table 2. Results of regression analysis of management capabilities.

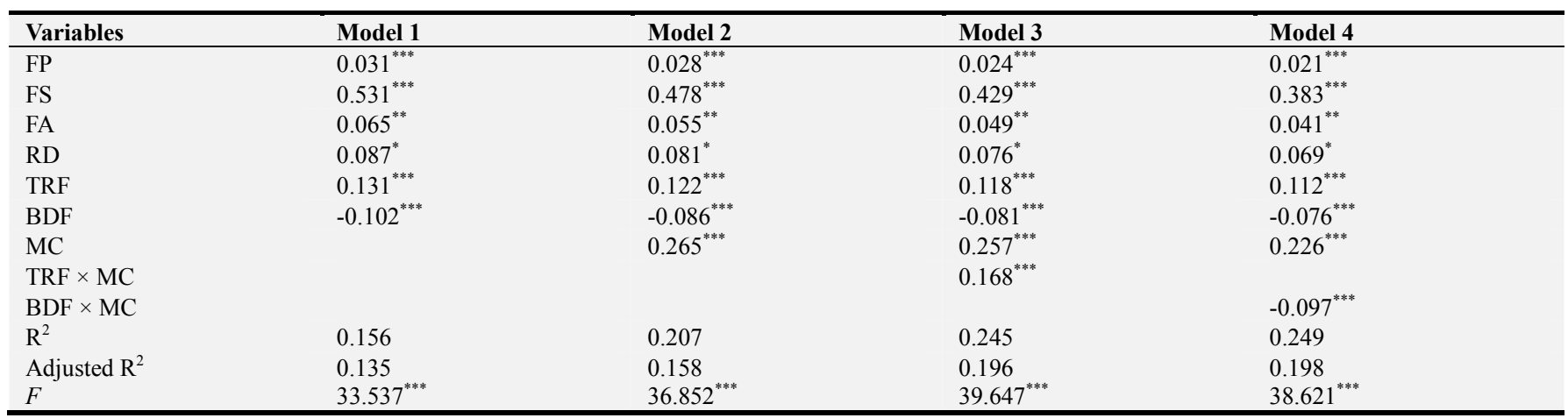

Notes: $\mathrm{N}=163 ; * * *$ Significance level at $\mathrm{p}<0.01 ; * *$ Significance level at $\mathrm{p}<0.05$; ${ }^{*}$ Significance level at $\mathrm{p}<0.1$.

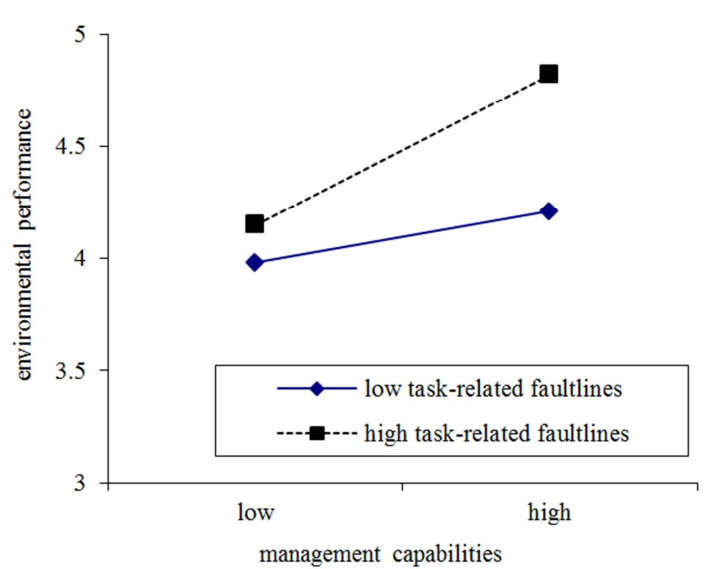

(a)

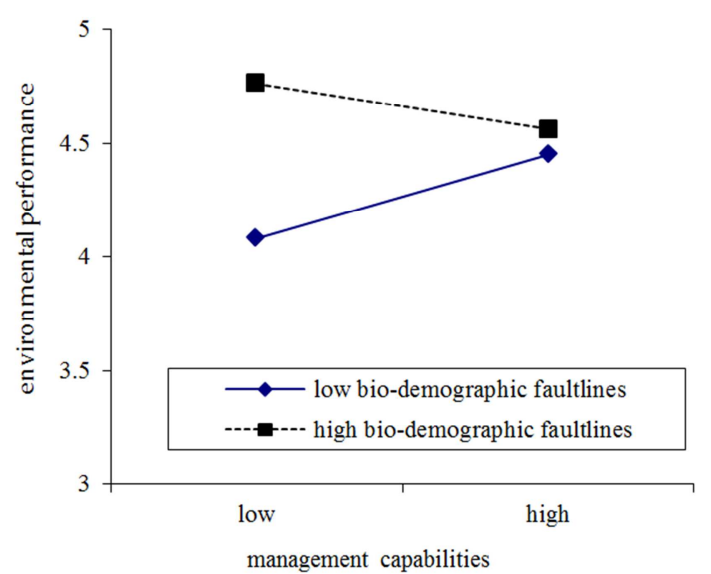

(b)

Figure 1. Moderating effect of top management team faultlines: (a) Moderating effect of top management team task-related faultlines; (b) Moderating effect of top management team bio-demographic faultines. 


\section{Discussion}

\subsection{Implications for Theory}

The environmental performance is significant important for the firms to achieve the sustainable development. Several scholars have suggested that environmental management capabilities have significant and positive impact on corporate environmental performance [41], but the discussion of the effect of management capabilities on corporate environmental performance, especially the moderating effect of top management team faultlines on the relationship between management capabilities and corporate environmental performance has not yet been investigated empirically. The primary aim of this study is to address this gap through analyzing management capabilities as a micro-level origin of corporate environmental performance because top management team plays an important role in the conversion of resources into environmental performance [4].

The major finding of this study is that management capabilities have a significant and positive influence on corporate environmental performance. The findings confirm that theoretical considerations about the impact of micro-level origins of corporate environmental performance. The results stress that the fact that management capabilities are important for boosting corporate environmental performance.

Another finding of this study is that top management team faultlines have a significant moderating effect on the relationship between management capabilities and environmental performance. Specifically, top management team task-related faultlines have a significant and positive influence on the relationship between management capabilities and environmental performance, whereas top management team bio-demographic faultlines have a significant and negative influence on the above relationship.

The findings of this study answer the research questions and encourage more scholars to discuss the factors influencing environmental performance from the perspective of top management team. The results indicate that management capabilities as an important micro-level origin in the firms influence environmental performance. With a view to the theoretical background, the attentions about the relevant researches should be paid to discuss the influence of top management team social capital including social network and political connection on environmental performance because social capital is one of the important resources of the firms. In addition, the environmental dynamics should be considered as moderators in further researches about social capital as important micro-level origin of environmental performance.

\subsection{Implications for Practice}

This study provides several implications for practice, the stronger level of management capabilities the firms have, the better corporate environmental performance becomes. Therefore, in order to boost environmental performance, increasing management capabilities is very crucial.
Due to the significant and positive and negative moderating effect of top management team task-related and bio-demographic faultlines, it is very important for the firms to strengthen top management team task-related faultlines and weaken top management team bio-demographic faultlines to improve corporate environmental performance. Specifically, when establishing and optimizing top management team, the firms should consider the top management team task-related faultlines including functional background, educational level, and tenure. It is in favor of boosting corporate environmental performance if top management team task-related faultlines increase. Meanwhile, the firms should consider the top management team bio-demographic faultlines including age and gender, because it is in favor of boosting corporate environmental performance if top management team bio-demographic faultlines decrease.

\subsection{Limitations and Future Research}

Although this study empirically investigates the influence of management capabilities on corporate environmental performance, and the moderating role of top management team faultlines for the above relationship, its empirical analysis imposes several limitations.

First, the data from this study only considers the cross-section level without taking into account the relationship between the variables from the time-series perspective. In view of objective measurement method of management capabilities [42] and corporate environmental performance [4], future researches could apply panel data on Chinese listed firms to empirically analyze the impacts of management capabilities on environmental performance of the firms to offer a more generalized conclusion across industries in Chinese context.

Second, since this study tests the proposed hypotheses with a sample consisting exclusively of Chinese chemical firms, it would be helpful and interesting to conduct a similar research in the other countries with different culture, such as western countries, in order to test the proposed hypotheses, especially the latter two hypotheses proposed in this study, because culture norms and rules govern how individual and organizational behave influence the outcomes of the firms.

\section{Conclusion}

This study empirically investigates the influence of management capabilities on corporate environmental performance, and the moderating effect of top management team faultlines on the above relationship. The results show that management capabilities have a significant and positive impact on corporate environmental performance. Meanwhile, top management team task-related faultlines have a significant and positive moderating effect on the relationship between management capabilities and environmental performance, whereas top management team bio-demographic faultlines have a significant and negative moderating effect for the above relationship. The findings could provide the firms with 
some valuable theoretical references on establishing a better understanding of how top management team influence corporate environmental performance.

\section{Acknowledgements}

This work was supported by the National Social Science Foundation of China (Grant No. 17BGL041).

\section{References}

[1] Katz, R. L. Skills of an effective administrator. Harv. Bus. Rev. 1974, 52, 90-102.

[2] Ruiz-Jiménez, J. M.; Fuentes-Fuenntes, M. M. Management capabilities, innovation, and gender diversity in the top management team: An empirical analysis in technology-based SMEs. BRQ-Bus. Res. Q. 2016, 19, 107-121.

[3] Georgakakis, D.; Greve, P.; Ruigrok, W. Top management team faultlines and firm performance: Examining the CEO-TMT interface. Leadersh. Q. 2017, 28, 741-758.

[4] Zou, H. L.; Zeng, S. X.; Lin, H.; Xie, X. M. Top executives' compensation, industrial competition, and corporate environmental performance: Evidence from China. Manag. Decis. 2015, 53, 2037-2059.

[5] Long, X. L.; Chen Y. Q.; Du, J. G.; Oh, K.; Han, I. The effect of environmental innovation behavior on economic and environmental performance of 182 Chinese firms. J. Clean. Prod. 2017, 166, 1274-1282.

[6] Dubey, R.; Gunasekaran, A.; Helo, P.; Papadopoulos, T. Explaining the impact of reconfigurable manufacturing system on environmental performance: The role of top management and organizational culture. J. Clean. Prod. 2017, 141, 56-66.

[7] Xie, X. Y.; Wang, W. L.; Qi, Z. J. The effects of TMT faultline configuration on a firm's short-term performance and innovation activities. J. Manag. Organ. 2015, 21, 558-572.

[8] Lau, D. C.; Murnighan, J. K. Demographic diversity and faultlines: The compositional dynamics oforganizational groups. Acad. Manag. Rev. 1998, 23, 325-340.

[9] Srikanth, K.; Harvey, S.; Peterson, R. A dynamic perspective on diverse teams: Moving from the dual-process model to a dynamic coordination-based model of diverse team performance. Acad. Manag. Ann. 2016, 10, 453-493.

[10] Thatcher, S.; Jehn, K.; Zanutto, E. Cracks in diversity research: the effects of diversity faultlines on conflict and performance. Group Decis. Negot. 2003, 12, 217-241.

[11] Vandebeek, A.; Voordeckers, W.; Lambrechts, F.; Huybrechts, J. Board role performance and faultlines in family firms: The moderating role of formal board evaluation. J. Fam. Bus. Strateg. 2016, 7, 249-259.

[12] Hutzschenreuter, T.; Horstkotte, J. Performance effects of top management team demographic faultlines in the process of product diversification. Strateg. Manag. J. 2013, 34, 704-726.

[13] Penrose, E. The Theory of the Growth of the Firm. John Wiley, Nueva York, 1959.

[14] Martin, J. A., Dynamic managerial capabilities and the multi-business team: The role of episodic teams in executive leadership groups. Organ. Sci. 2011, 22, 118-140.

[15] Maggitti, P. G.; Smith, K. G.; Katila, R. The complex search process of invention. Res. Policy. 2013, 42, 90-100.

[16] Jehn, K. A. A multimethod examination of the benefits and detriments of intragroup conflict. Adm. Sci. Q. 1995, 40, 256-282.

[17] Basco, R.; Voordeckers, W. The relationship between the board of directors and firm performance in private family firms: A test of the demographic versus behavioral approach. J. Manag. Organ. 2015, 21, 1-25.

[18] Tanikawa, T.; Jung, Y. Top management team (TMT) tenure diversity and firm performance: Examining the moderating effect of TMT average age. Int. J. Organ. Anal. 2016, 24, 454-470.

[19] Carpenter, M. A.; Fredrickson, J. W. Top management teams, global strategic posture, and the moderating role of uncertainty. Acad. Manag. J. 2001, 44, 533-545.

[20] Stasser, G.; Taylor, L. A.; Hanna, C. Information sampling in structured and unstructured discussion of three- and six-person groups. J. Pers. Soc. Psychol. 1989, 57, 67-78.

[21] Gibson, C.; Vermeulen, F. A healthy divide: subgroups as a stimulus for team learning behavior. Adm. Sci. Q. 2003, 48, 202-239.

[22] Barkema, H. G.; Shvyrkov, O. Does top management team diversity promote or hamper foreign expansion? Strateg. Manag. J. 2007, 28, 663-680.

[23] Hinsz, V. B.; Tindale, R. S.; Vollrath, D. A. The emerging conceptualization of groups as information processors. Psychol Bull. 1997, 121, 43-64.

[24] Ndofor, H.; Sirmon, D.; He, X. Utilizing the firm's resources: How TMT heterogeneity and resulting faultlines affect TMT tasks. Strateg. Manag. J. 2015, 36, 1656-1674.

[25] Chen, S.; Wang, D. X.; Zhou, Y. Chen, Z. G.; Wu, D. Y. When too little or too much hurts: Evidence for a curvilinear relationship between team faultlines and performance. Asia Pac. J. Manag. 2017, 34, 931-950.

[26] Veltrop, D. B.; Hermes, N.; Postma, T. J.; Haan, J. A tale of two factions: Why and when factional demographic faultlines hurt board performance. Corp. Gov. 2015, 23, 145-160.

[27] Milliken, F. J.; Martins, L. L. Searching for common threads: Understanding the multiple effects of diversity in organizational groups. Acad. Manag. Rev. 1996, 21, 402-433.

[28] Bell, S. T.; Villado, A. J.; Lukasik, M. A.; Belau, L.; Briggs, A. L. Getting specific about demographic diversity variable and team performance relationships: A meta analysis. J. Manag. 2011, 37, 709-743.

[29] Hogg, M. A.; Terry, D. J. Social identity and self categorization processes in organizational contexts. Acad. Manag. Rev. 2000, $25,121-140$.

[30] Li, J.; Hambrick, D. C. Factional groups: A new vantage on demographic faultlines, conflict, and disintegration in work teams. Acad. Manag. J. 2005, 48, 794-813.

[31] Pearsall, M. J.; Ellis, A. P.; Evans, J. M. Unlocking the effects of gender faultlines on team creativity: Is activation the key? J. Appl. Psychol. 2008, 93, 225-234. 
[32] Simons, T. L.; Peterson, R. S. Task conflict and relationship conflict in top management teams: The pivotal role of intragroup trust. J. Appl. Psychol. 2000, 85, 102-111.

[33] Sawyer, J. E., Houlette, M. A., Yeagley, E. L. Decision performance and diversity structure: Comparing faultlines in convergent, crosscut, and racially homogeneous groups. Organ. Behav. Hum. Decis. Process. 2006, 99, 1-15.

[34] Hambrick, D. C.; Mason, P. A. Upper echelons: the organization as a reflection of its top managers. Acad. Manag. Rev. 1984, 9, 193-206.

[35] Eshima, Y.; Anderson, B. S. Firm growth, adaptive capability, and entrepreneurial orientation. Strateg. Manag. J. 2017, 38, 770-779.

[36] Darnall, N.; Henriques, I.; Sadorsky, P. Adopting proactive environmental strategy: The influence of stakeholders and firm size. J. Manage. Stud. 2010, 47, 1072-1094.

[37] Miller, D.; Chen, M. J. Sources and consequences of competitive inertia: A study of the US airline industry. Adm. Sci. Q. 1994, 39, 1-23.
[38] Delmas, M.; Toffel, M. W. Stakeholders and environmental management practices: An institutional framework. Bus. Strateg. Environ. 2004, 13, 209-222.

[39] Firth, M.; Fung, P. M.; Rui, O. M. Corporate performance and CEO compensation in China. J. Corp. Financ. 2006, 12, 693-714.

[40] Aiken, L. S.; West, S. G. Multiple regression testing and interpreting interactions. Newbury Park, CA: Sage, 1991.

[41] Liang, D. P.; Liu, T. S. Does environmental management capability of Chinese industrial firms improve the contribution of corporate environmental performance to economic performance? Evidence from 2010 to 2015. J. Clean. Prod. 2017, 142, 2985-2998.

[42] Demerjian, P.; Lev, B.; McVay, S. Quantifying managerial ability: A new measure and validity tests. Manag. Sci. 2012, 58, 1229-1248. 